\title{
Recombinant Thyrotropin Alfa
}

National Cancer Institute

\section{Source}

National Cancer Institute. Recombinant Thyrotropin Alfa. NCI Thesaurus. Code C61322.

A recombinant form of the human anterior pituitary glycoprotein thyroid stimulating hormone (TSH) with use in the diagnostic setting. With an amino acid sequence identical to that of human TSH, thyrotropin alfa binds to TSH receptors on normal thyroid epithelial cells or well-differentiated thyroid cancer cells, stimulating iodine uptake and organification, synthesis and secretion of thyroglobulin (Tg), triiodothyronine (T3), and thyroxine (T4). 